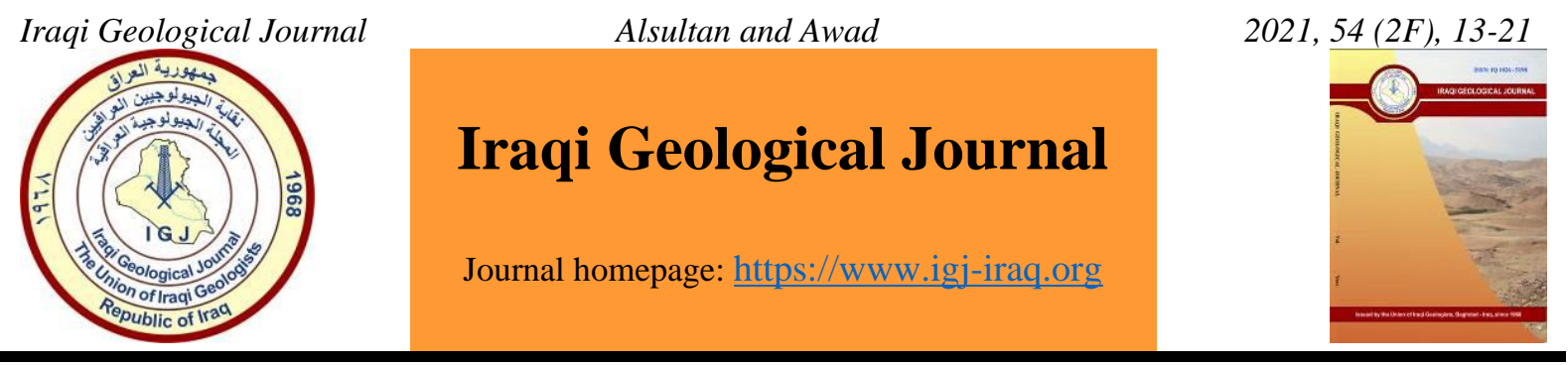

\title{
Sequence Stratigraphy of the Fatha Formation in Shaqlawa Area, Northern Iraq
}

\author{
Hamid A. A. Alsultan ${ }^{1, *}$ and Karrar Hassooni Awad ${ }^{2}$ \\ 1 Department of Applied Geology, College of Science, University of Babylon, Babylon, Iraq \\ 2 Directorate General of Education in Babylon Province, Babylon, Iraq \\ * Correspondence: sci.hamid.ali@uobabylon.edu.iq
}

Received: 7 October 2021; Accepted: 25 October 2021; Published: 31 December 2021

\begin{abstract}
A surface section of the Fatha Formation (Middle Miocene) was studied in the Shaqlawa area, Erbil, Northern Iraq. It consists of siliciclastic silt, evaporates, and carbonates in a mixed siliciclastic silt composition. The Fatha Formation in the study area can be divided into two members of variable thickness based on rocky differences. Depositional settings ranged from shallow open-marine and restricted-hypersaline to supratidal and continental (sabkha, fluvio-deltaic, and exposure). It is bounded below by a type one sequence boundary above the Eocene Pila Spi Formation and marked by conglomerates. The upper sequence boundary with the Injana Formation is conformable. Thirteen sedimentary facies were distinguished in the Fatha Formation within the Shaqlawa region of northern Iraq and include sandstone to mudstone, wavy bedded sandstone to mudstone, Flaser bedded sandstone to mudstone, Marl, sandstone, cross lamination sandstone, Trough cross bedded sandstone, Planar cross bedded sandstone, marly limestone lithofacies, bioclastic grainstone to packstone microfacies, bioclastic lime mudstone to wackestone microfacies, lime mudstone-wackestone microfacies, and gypsum lithofacies. The depositional environment of the formation was inferred based on the facies association concepts. The succession formation can be divided into several third-order cycles, which reflect fluctuations in the relative sea-level rise. High-frequency cycles of transgressive System Tract and Highstand System Tract. Fundamental to the evolution of the sequence, in this case, is the local tectonic component.
\end{abstract}

Keywords: Fatha Formation; Sequence stratigraphy; Middle Miocene; Microfacies; Northern Iraq

\section{Introduction}

Busk and Mayo (1918) first identified the Lower Fars Formation in Iran's Fars Province, although they didn't provide a type location (van Bellen et al., 1959). Makhul-Hamrin Range. Al-Rawi et al. (1993) presented this suggestion. One of Iraq's most widely distributed formations is the Middle Miocene Fatha Formation (Jassim and Buday, 2006). It's mostly evaporitic, with alternating mud rocks, limestones, gypsum, anhydrite, and halite forming multiple shallowing-upward cycles. It is an essential part of the petroleum system since it serves as a regional seal for many oil reservoirs in Iraq (Alkhafaji et al., 2022; Awadh and Al-Mimar, 2018), and it is also a reservoir in many fields (Metwalli et al., 1974). In addition, Jassim et al. (1999) discovered commercially important sulfur deposits in evaporite beds

DOI: $10.46717 /$ igj.54.2F.2ms-2021-12-19 
mostly composed of gypsum and anhydrite, as well as sulfate and salt (Jassim et al., 1999). In theMosul and Heet atras, The Fatha Formation contains a lot of native sulfur deposits (Awadh and Al-Ankaz,2016a).

Biostratigraphy cannot be used to determine the age of the Fatha Formation. It has been interpreted as Middle Miocene (Sharland et al., 2004). Strontium isotopes have dated the base of the Gachsaran Formation in Iran, which is thought to be comparable to the Fatha Formation in southern Iraq, as Early Miocene, Mid-Burdigalian (Ehrenberg et al., 2007). The Fatha Formation is emplacement on the Euphrates Formation and both are of wide spread exposures (Awadh et al., 2013; Awadh and Ahmed, 2013; Awadh, 2014). The Fatha Formation was deposited in lagoon environment over basinal facies (Al-Dabbas et al., 2013; Al-Dabbas et al., 2014; Awadh and Al-Ankaz, 2016b; Awadh and Al-Ankaz, 2016c). This study mainly aims to determine the sedimentary environment through a detailed petrographic study and analysis of the sedimentary features of a selected section within the study area. This is one of the main requirements for stratified sequence analysis to develop the middle Miocene sequence and to show the effect of fluctuation in sea level on the development of the sequence.

\section{Methodology and Study Area}

The study area is located in northern Iraq, in the Erbil Governorate, near the city of Shaqlawa (Fig.1). In Shaqlawa city ( $36^{\circ} 25^{\prime} 11.15^{\prime \prime}$ N) $\left(44^{\circ} 20^{\prime} 20.18^{\prime \prime}\right.$ E), researchers studied one composite section. This section yielded eighty samples, with the chosen samples focusing on facies, color changes, and bed hardness. Preparation of ninety-six thin sections for collecting samples to investigate the microfacies in these successions. The Fatha Formation is made up of marl, limestone, marly limestone, gypsum, siltstone, claystone, sandstone, shale and spans a total thickness of $186 \mathrm{~m}$. The Fatha Formation is divided into two distinct rock units. The Lower Member has an average thickness of 85 meters and is made up of marl, limestone, marly limestone, and gypsum (Fig. 2A). marl, siltstone, claystone, sandstone, shale, and gypsum make up the Upper Member of the formation which has a thickness of 101 meters (Fig. 2B).

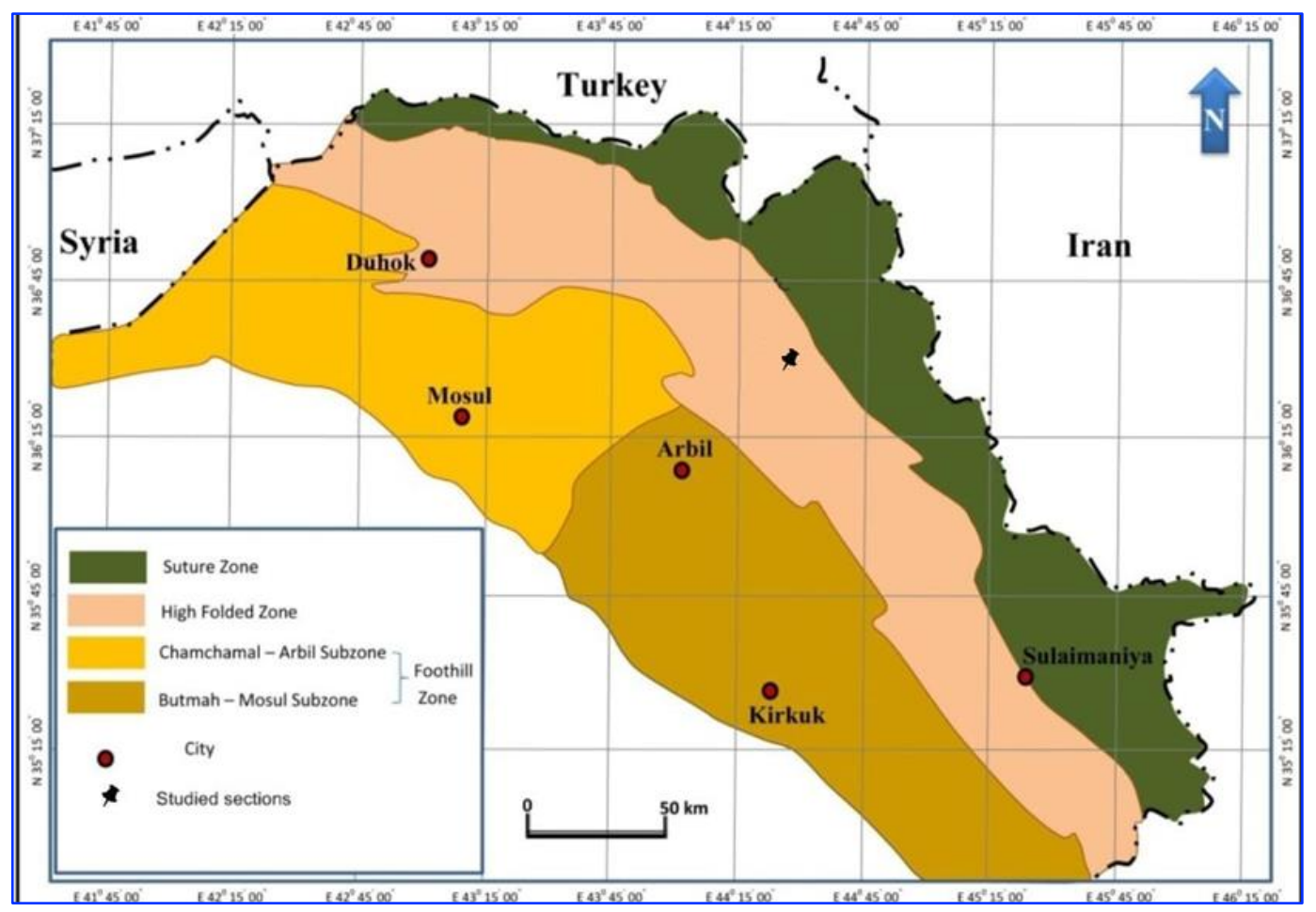

Fig. 1. Location map of the study area (after Jassim and Goff 2006) 


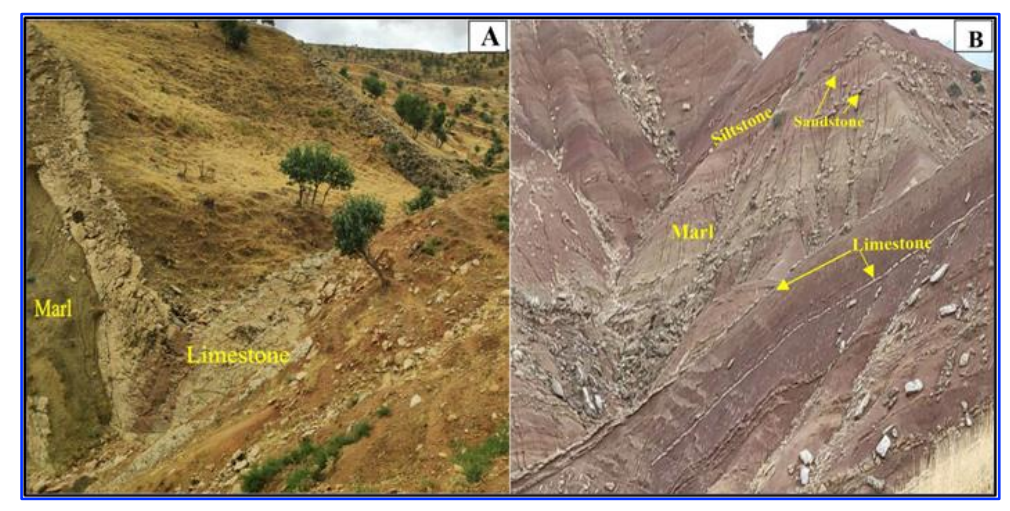

Fig. 2. A) Thick bedded marl and limestone at the lower part of the Fatha Formation; B) Interbreeding of thick bed of sandstone with claystone and siltstone at the upper part of Fatha Formation

\section{Results}

\subsection{The Lithofacies of the Fatha Formation}

The Fatha Formation succession is made up of a variety of mud rocks, limestones, and gypsum. It is divided into two distinct rock units. The Lower Member, which has a basal unit of organo-detrital limestone and anhydrite (or gypsum), green dolomitic marl and thin limestone, and cyclically interbedded gypsum, green marl, and limestone. The Upper Member is made up of cyclic red and green mudstones, gypsum, and thin gray limestone layers with calcarenite beds on top. According to the findings, the Fatha Formation may be classified into four major lithofacies based on the prevalent lithology.

\subsection{Sandstone to Mudstone Lithofacies}

It is mostly made up of fine to medium-grained sandstone layers, cement-backed to brittle sandstone layers, shale, thin carbonate layers (limestone, dolomitic limestone, dolostone), and layered stone strips. The thickness of these lithofacies varied from 2.5 to $13.5 \mathrm{~m}$, and they made up approximately $37.9 \%$ of all facies assessed. This facies is extensively distributed across the formation's top component (Fig. 3A). These chambers include two tiny rooms:

\subsubsection{Wavy-bedded sandstone to mudstone sublithofacies}

This sub lithofacies indicates a change in the velocity of the current, where sandstone deposits represent high energy depositional conditions, while mudstone deposits indicate calm water sedimentary conditions. This applies to the effects of tidal currents on tidal flats and deltas (Fig. 3B).

\subsubsection{Flaser-bedded sandstone to mudstone sublithofacies}

This facies was represented by thin beds that did not exceed 1 meter, which was located within the upper member of the formation. These facies reflect the alternating currents with the movement of the waves in a calm water environment (Fig. 3C).

\subsection{Sandstone Lithofacies}

These rock strata consist primarily of fine to medium-grained sandstone layers, and these are vertically sliced by thin layers of shale, siltstone, and sometimes limestone. Three sub lithofacies are distinguished within these facies. 


\subsubsection{Parallel and cross lamination sandstone sublithofacies}

This facies is characterized by fine to medium-sized sandstone grains and reflects low-energy depositions of flood currents such as calm water tidal flats, overbank, and levees should be reflected in such cross lamination (Fig. 3D). While bioturbation indicates active sedimentation in the prodelta channels and rivers, bioturbulence in the form of a mottled structure does not necessarily indicate active sedimentation (Caradaghi et al., 2008).

\subsubsection{Trough cross bedded sandstone sublithofacies}

It is represented by light brown to gray sandstone with fine to very fine grains. This facies may reflect small current ripples and waves deposited in the channel sediments, tidal channels, and distributed mouth bars.

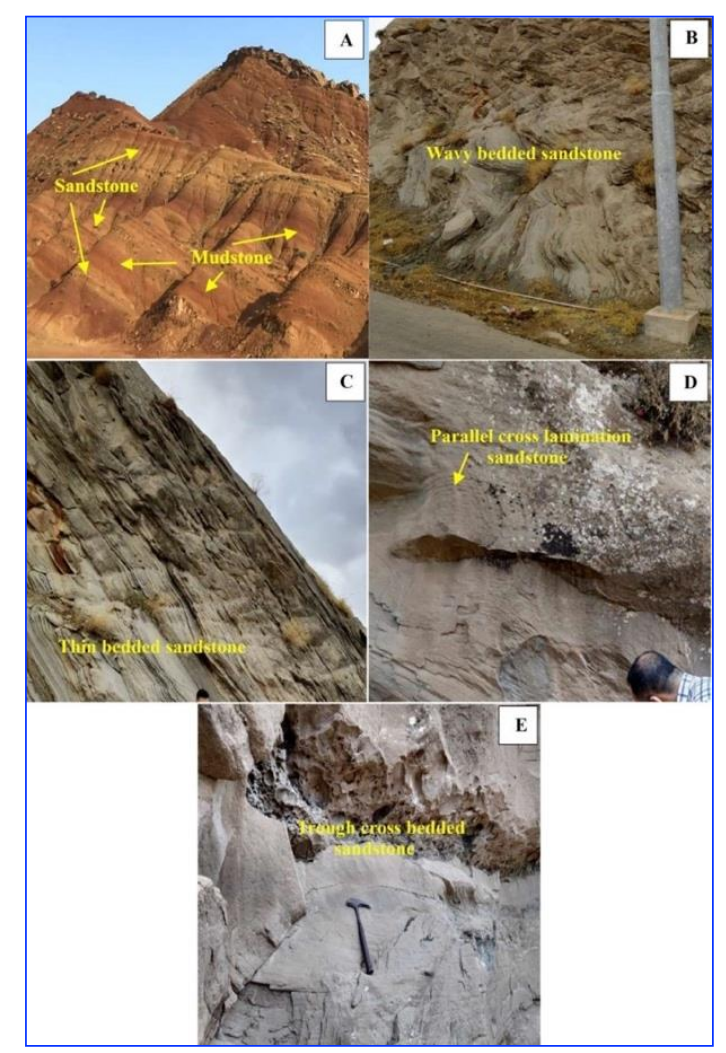

Fig. 3. A)Thick bedded sandstone and mudstone at the upper part of Fatha Formation, B)wavy bedded sandstone to mudstone, C) Thin bedded sandstone, D) Parallel cross lamination sandstone, and E- Trough cross bedded sandstone

\subsubsection{Planar cross bedded sandstone sublithofacies}

This facies consists of sandstone beds with low-angle cross bedding, with an angle of fewer than 10 degrees. It may reflect this facies delta environment distributary channels and is supposed to suggest actively sinking prodelta basins (Qaradaghi et al., 2008).

\subsection{Marly Limestone lithofacies}

Yellowish grey, lightly bedded to laminated, and fossiliferous limestone in nature. Internal features such as flaser bedding, wavy laminations, and stromatolites that alternate with arenaceous limestones are common. Marly limestones are found at the bottom of most carbonate horizons, although 
it contains more dolomite with its presence under the layers of gypsum, with a significant decrease in fossil richness. (Fig. 4A).

\subsection{Limestone Lithofacies}

\section{These facies divided into:}

\subsubsection{Bioclastic grainstone to packstone microfacies}

The kind and quantity of bioclasts present distinguish several sub microfacies. Gastropods, rotalids, miliolids, pelecypods, echinoids, and calcareous algae are examples of bioclasts (Fig.-4B). Pellets come in a variety of shapes and sizes, ranging from ovoid to sub-rounded. Ooids, mainly micritized grains with a noticeable concentric structure, are also found. The typical bladed and sparry calcite cement may have come from a phreatic meteor (Tucker, 1993). The bioclastic-packstone was deposited on the edge of a shoal in a platform setting; the sediments were deposited in a shallow-marine environment (Flugel, 2010).

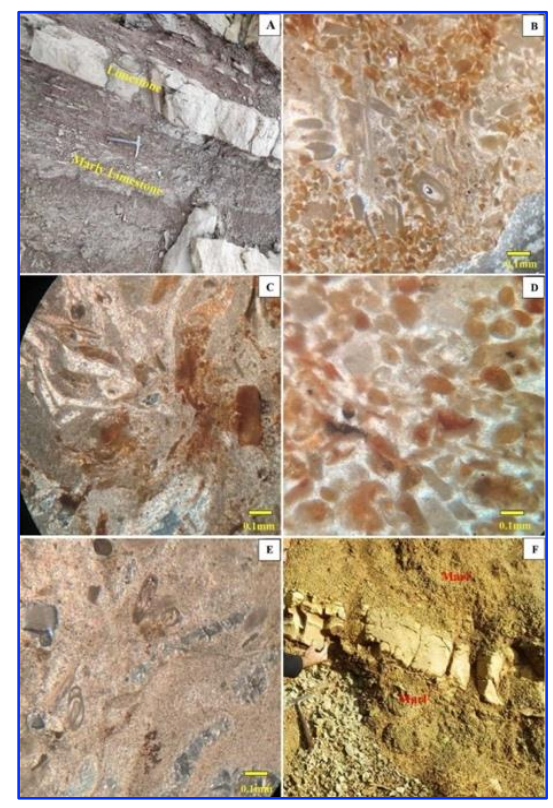

Fig. 4. A) Thin bedded marly limestone and limestone at the lower part of Fatha Formation, B- Bioclastic Grainstone to Packstone Microfacies; C) Bioclastic wackestone Microfacies, D- Peloidal packstone Microfacies, E- Lime Mudstone-Wackestone Microfacies, and E- Marl lithofacies

\subsubsection{Bioclastic Lime Mudstone to wackestone Microfacies}

Fine-grained and micritic limestone with small quantities of silt- and sand-sized grains, mostly quartz, characterizes this microfacies. It mainly affects the lower member's upper portion, although they may also be dolomitized and porous. Bioclasts such as bryozoans, gastropods, ostracods, and benthic foraminifera are abundant (Fig. 4C). Pellets are usually ovoid and micritized with sparry calcite envelopes. Euhedral dolomite crystals may also be used to fill the gaps. These sediments were deposited at modest depths and low energy under calm, shallow-water marine settings.

\subsubsection{Peloidal packstone microfacies}

This facies is characterized by the presence of an abundance of fine peloids, bioclasts, and fossils. It is characterized by partial or complete destruction of grains by recrystallization. This facies probably represents intermediate energy conditions (Fig. 4D). 


\subsubsection{Lime mudstone-wackestone microfacies}

This microfacies is fine-grained, containing a few uncommon fossil phantoms. Gypsum is used to fill some of the resulting spaces (Fig. 4E). The lime muds are mostly peloidal, with a few ostracods, foraminifera, and calcispheres thrown in for good measure. The limestone beds have a low-diversity benthic foraminifera composition that is devoid of planktonic foraminifera. The presence of microbial laminates and fenestral-fabric textures indicates that these sediments were deposited in an intertidal environment. Evaporative circumstances may be indicated by the occurrence of palygorskite as an authigenic mineral. Chamley (1989) outlined the requirements for the development of alkaline palygorskite in a constrained warm, humid, highly evaporative basin with limited water exchange.

\subsection{Marl Lithofacies}

This facies is found nearly everywhere throughout the formation. The light grey and green marl facies is interbedded with Gypsum and is connected with thin-bedded carbonate (Fig. 4F). These general characteristics of the investigated succession suggest that it was formed in a subtidal environment. The grey marls are more likely to have been influenced by the sea, while the red mudstones are more likely to have been exposed to the sea.

\subsection{Gypsum Lithofacies}

Sulphide account for approximately $40 \%$ of the formation's overall thickness, with beds varying in thickness from 0.2 to $0.5 \mathrm{~m}$. Despite the presence of laminated and thick-bedded gypsum, nodular gypsum is the most frequent. Laterally and vertically, nodular gypsum changes from thick to very thickbedded gypsum. There is also secondary gypsum. Nodular gypsum deposition may indicate a very shallow, dry, semi restricted marine environment that experienced reflux and inflow activities. Shawkat and Tucker (1978) determined that the gypsum beds were formed in a sabkha or supratidal flat environment; a coastal or inland sabkha with a semi-barred, shallow lagoon has also been proposed (Awad and Alsultan, 2020).

\section{Depositional Environments}

The sedimentary environments in the Fatha Formation are identified by studying the various sedimentary facies. The presence of several sedimentary habitats in the vent formation was determined by the coastal influence in the middle formation, delta environments in the upper formation, and the influence of interior shelf environments in lower parts, as shown in Fig. 5. The lower member of the Fatha Formation is represented by microfacies of Bioclastic-Peloidal Lime Mudstone-Wackestone the most frequent bioclasts found include bryozoans, gastropods, ostracods, and benthic foraminifera. There are microfacies with little fossil remnants. These sediments were deposited at intermediate depths and low energy under calm, shallow-water marine settings. Bioclastic-Peloidal Grainstone-Packstone Microfacies: Gastropods, miliolids, pelecypods, bryozoans, echinoids, ostracods, and calcareous algae are examples of bioclasts. The typical bladed and sparry calcite cement may have been deposited in a shallow-marine condition, whereas the bioclastic-packstone was formed on the edge of a shoal in a platform setting (Tucker, 1993). Lime Mudstone-Wackestone Microfacies deposited in an intertidal environment. The formation of nodular gypsum reflects a very shallow, dry, semi-restricted marine environment subjected to reflux and inflow processes. Alternatively, the gypsum deposits may be deposited in a sabkha or supratidal flat environment, such as a coastal or inland sabkha with a semibarred, shallow lagoon (Alsultan et al., 2021).

Sandstone, silty claystone, and claystone represented the upper member of formation, which has coarsening upward cycles. During a time of delta progradation within the lagoonal sediments, the 
coarsening-upward Deltaic Cycle emerged. It is found under the Limestone layers and has a thickness of 6-15.4 meters (Fig. 5). The quartz-rich sandstones are fluvio-deltaic deposits that are thought to have originated in elevated areas of the Zagros and Taurides Mountain ranges (Aqrawi, 1993). The topmost sandstone may be upper delta plain deposits produced when flowing water reached a stagnant water body and the current velocity dropped. The thin limestone layers were formed in a low-energy marine (limited) environment after a marine flooding event temporarily decreased clastic input into the basin.

\section{Sequence Development}

The Fatha Formation (Miocene) was deposited as a transgressive-regressive sequence in a broad shallow foreland basin adjacent to the Zagros-Taurus collisional belt. Depositional settings ranged from shallow open-marine and restricted-hypersaline to supratidal and continental (sabkha, fluvio-deltaic, and exposure). It is bounded below by a Type one sequence boundary above the Eocene Pila Spi Formation and marked by conglomerates. The upper sequence boundary with the Injana Formation is conformable. High-frequency cycles of alternating greenish grey and reddish-brown marls and flooded limestones, topped by gypsum and/or anhydrite and halite, define the Fatha Formation. High-frequency marine transgressions are shown by thin marly limestone layers at the beginning of each cycle represented Transgressive System Tract (TST) (Fig. 5). Following evaporation, a period of regression began, resulting in the formation of large supratidal sabkhas dominated by nodular gypsum and/or anhydrites represented High Stand System tract (HST) (Fig. 5). The basin edges are dominated by thin evaporites that are linked with red claystones and litharenites. The last vestiges of the receding sea in Salinas, or salt pans, are represented by halite deposition in the basin center. Carbonates, evaporites, and siliciclastic are deposited in a cyclic pattern, indicating recurrent flooding followed by limitation and continental exposure. In Iran's partially coeval Gachsaran Formation, similar cyclicity occurred

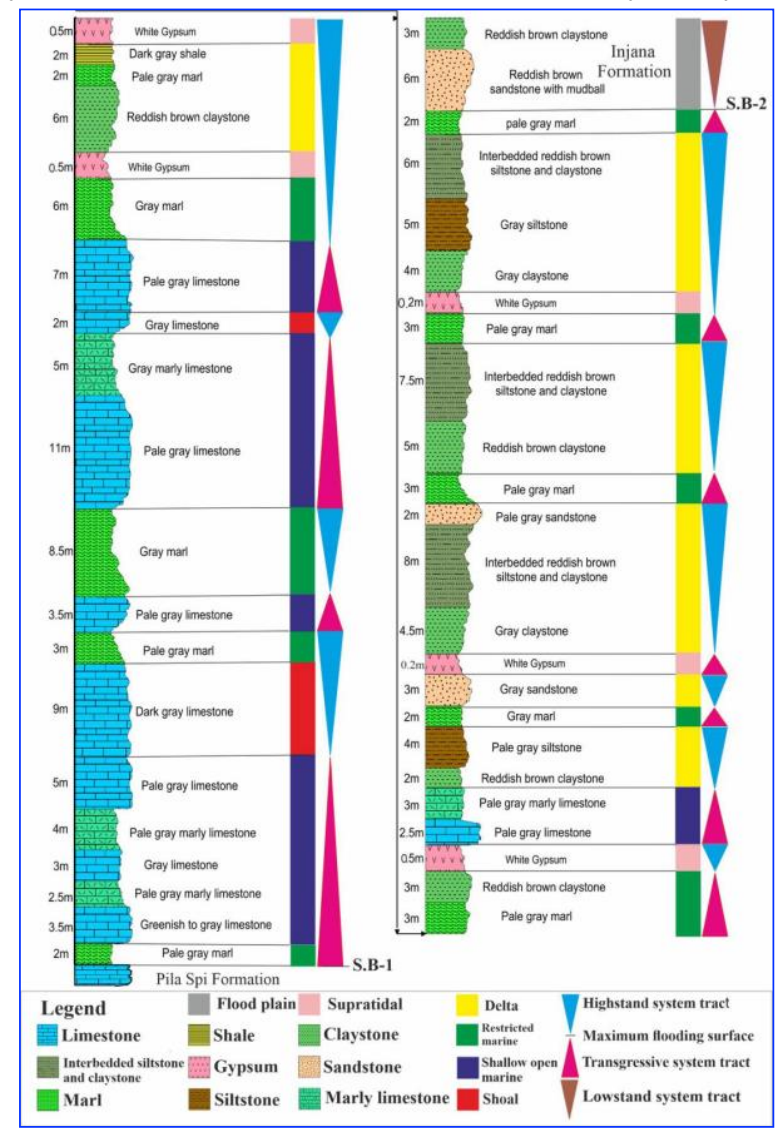

Fig. 5. Sequence stratigraphy subdivision of Fatha Formation in the study area 


\section{Conclusions}

In this study, Thirteen sedimentary facies were distinguished in the Fatha Formation within the Shaqlawa region of northern Iraq and: Marl, wavy bedded sandstone to mudstone, and flaser bedded sandstone to mudstone sublithofacies, sandstone include parallel to cross lamination sandstones, trough cross-bedded sandstone, and Planar cross-bedded sandstone sublithofacies, bioclastic grainstone to packstone microfacies, bioclastic lime mudstone to wackestone microfacies, and lime mudstonewackestone microfacies are the three microfacies that make up the limestone lithofacies. These lithofacies are arranged vertically indicating that the Fatha Formation in the study area comprises several shallowing-upwards cycles starting with shallow marine deposits and ending with complete drying of the basin (desiccation) represented by continental deposition. The depositional basin of the Fatha Formation comprises a shallow-water marine setting with lagoons. The nodular gypsum is most probably deposited in a sabkha or supratidal flat environment, such as a coastal or inland sabkha with a semi-barred, shallow lagoon, and indicates a hot and arid climate. Sandstone, silty claystone, and claystone represented the upper member of formation, which has coarsening upward cycles. During a time of delta progradation within the lagoonal sediments, The Fatha Formation can be divided into two units named unit 1, and unit 2 (in ascending order). The succession may be split into third order cycles, which reflect variations in sea level increases and relative sea level stillstands. High-frequency cycles of alternating Transgressive System Tract (TST) and High Stand System tract (HST). The primary regulating element on sequence evolution in this instance is the local tectonic component.

\section{Acknowledgments}

The authors are very grateful to the Editor in Chief Prof. Dr. Salih M. Awadh, the Secretary of Journal Mr. Samir R. Hijab. and the Technical Editors for their great efforts and valuable comments.

\section{References}

Al-Dabbas, M., Awadh, S.M. and Zaid, A.A., 2013. Mineralogy, geochemistry, and reserve estimation of the Euphrates limestone for Portland cement industry at Al-Najaf area, South Iraq. Arabian Journal of Geosciences, 6(2), 491-503.

Al-Dabbas, M.A., Awadh, S.M. and Zaid, A.A., 2014. Facies analysis and geochemistry of the Euphrates Formation in Central Iraq. Arabian Journal of Geosciences, 7(5), pp.1799-1810.

Alkhafaji, M.W., Awadh, S.M., Connan, J., Engel, M.H., Al-Mimar, H.S., Al-Sulttani, A.H., Hussien, S.A., Mohammad, O.J. and Al-Ankaz, Z.S., 2022. Organic geochemistry of hydrocarbon seeps associated with sulfurous spring water, western Iraq: Biodegradation, source rock and sedimentary environment. Journal of Petroleum Science and Engineering, 208, p.109556.

Al-Rawi, Y.T., Sayyab, A. S., Al-Jassim, J. A., Tamar-Agha, M., Al-Sammarai, A.I., Karim, S.A, Basi, M.A, Hagopian D., Hassan, K.M., Al-Mubarak, M., Al-Badri, A., Dhiab, S.H, Faris, F.M. and Anwar, F., 1993. New names for some of the Middle Miocene-Pliocene formations of Iraq (Fatha, Injana, Mukdadiya and Bai Hassan formations). Iraqi Geological Journal, 25, 1-17.

Alsultan, A.A., Awadh, S.M., Al-Owaidi, M.R., and Al-Khafaji, A.J., 2021. Sequence Stratigraphy and Depositional Environment of the Zubair Formation in Rumaila Oilfields, Southern Iraq: Microfacies and Geochemistry. Iraqi Geological Journal, 54 (2B), 28-41

Aqrawi, A.A.M., 1993. Miocene evaporitic sequence of the southern Mesopotamian Basin. Marine and Petroleum Geology, 10, 172-179.

Awad, K. H., and Alsultan, H. A., 2020. Stratigraphic Analysis of Gercus Formation in Dohuk area, Northern Iraq. Iraqi Journal of Science, 61(9), 2293-2302

Awadh, S.M. and Ahmed, R.M., 2013. Hydrochemistry and pollution probability of selected sites along the Euphrates River, Western Iraq. Arabian Journal of geosciences, 6(7), 2501-2518.

Awadh, S.M. and Al-Ankaz, Z.S., 2016a. Sulfur isotopes geochemistry of the bituminous Fatha evaporates in Fatha Formation, Hit-Abu Jir area, western Iraq. The Iraqi Geological Journal, 39-40 (2),.34-45. 
Awadh, S.M. and Al-Ankaz, Z.S., 2016b. Geochemistry and petrology of Late Miocene-Pleistocene Dibdibba sandstone formation in south and central Iraq: implications for provenance and depositional setting. Arabian Journal of Geosciences, 9(8), 1-14.

Awadh, S.M. and Al-Ankaz, Z.S., 2016c. Inorganic geochemistry and origin of bitumen intruded in Euphrates and Fatha Formations in Hit area, western Iraq. Iraqi Journal of Science, 57(4A), 2478-2489.

Awadh, S.M., 2014. Stable carbon and nitrogen isotopes and elemental composition and origin of organic matter from the Neogene Euphrates, Injana and Dibdibba formations in Iraq: discrimination between marine and terrestrial environments. Geological Quarterly, 58, pp.729-736.

Awadh, S.M., Abood, Z.S. and Eisa, M.J., 2013. Chemical and physical control processes on the development of caves in the Injana Formation, Central Iraq. Arabian Journal of Geosciences, 6(10),.3765-3772.

Awadh, S.M., Al-Mimar, H.S. and Al-Yaseri, A.A., 2018. Salinity mapping model and brine chemistry of Mishrif reservoir in Basrah oilfields, Southern Iraq. Arabian Journal of Geosciences, 11(18), 1-12.

Chamley, H., 1989. Clay Sedimentology. Springer-Verlag, Berlin, 623 pp.

Ehrenberg, S.N., Pickard, N.A.H., Laursen, G.V., Monibi, S., Mossadegh, Z.K., Svn, T.A., Aqrawi, A.A.M., McArthur, J.M., And Thirlwall, M.F., 2007. Strontium isotope stratigraphy of the Asmari Formation (Oligocene-Lower Miocene), SW Iran. Journal of Petroleum Geology, 30(2), 107-128.

Flugel, E., 2010. Microfacies of Carbonate Rocks, 2nd ed. Springer-Verlag Berlin, Germany, 976 pp.

Jassim, S.Z., and Goff J.C., 2006. Geology of Iraq. Dolin, Prague and Moravian Museum, Zelny, Brno, Czech

Metwalli, M.H., Philip, G., and Moussl, M.M., 1974. Petroleum-bearing formations in northeastern Syria and Northern Iraq. American Association of Petroleum Geologists Bulletin, 58, 1781-1796.

Qaradaghi, A.I., Abdul-Kareem, B.M., Al-Jassim, J.A.,2008. Petrography diagenesis and depositional environment on Nahr Umr Formation, from selected wells in central Iraq. Iraqi Bulletin Geology Mining, 4(1), 67-94.

Sharland, P.R., Casey, D.M., Davies, R.B., Simmons, M.D., and Sutcliffe, O.E., 2004. Arabian Plate Sequence stratigraphy, Geo Arabia, 9(1), 199-219.

Tucker, M.E., 1993. Carbonate diagenesis and sequence stratigraphy. In, V.P. Wright (Ed.), Sedimentology Review. Blackwell Scientific Publications, 1, 51-72.

Van Bellen, R. C., Dunnington, H.V., Wetzel, R., and Morton, D., 1959. Lexique Stratigraphique International. Asia, Paris, 333 pp. 